\title{
Empirical Performance of Monetary Aggregates in BEAC and BCEAO
}

\author{
Mondjeli Mwa Ndjokou ${ }^{1, *}$ \\ ${ }^{1}$ Laboratoire d'Analyse et de Recherche en Economie Appliquée (LAREA), Faculty of \\ Economics and Management, University of Yaoundé II, Soa, Cameroon \\ *Correspondence: Laboratoire d'Analyse et de Recherche en Economie Appliquée (LAREA), \\ Faculty of Economics and Management, University of Yaoundé II, Soa, Cameroon \\ E-mail: motande@yahoo.fr
}

Received: November 17, 2012 Accepted: May 8, 2013 Published: June 12, 2013

doi:10.5296/rae.v5i2.1087ＵRL: http://dx.doi.org/10.5296/rae.v5i2.1087

\begin{abstract}
The aim of this study is to compare empirical performance of traditional as well as Divisia monetary aggregates. This evidence comes from the comparison of their relative performance in terms of real GDP and inflation within 1992.1 and 2007.4. For this purpose, the study uses in-sample and out-of-sample approaches. The in-sample approach focuses on variance decomposition analysis. Concerning out-of-sample analysis, a forecasting model is estimated through 2003:4 and forecast are generated for the period 2004:1- 2007:4. The study leads to the following results. Inflation and real GDP are better explained respectively by Divisia M2 and simple sum M2 in BEAC. In BCEAO, the contribution of each monetary aggregate to the fluctuations of inflation and real GDP is very worst except simple sum M2 in explaining price level. Considering the forecasting ability, it appears that at the narrowest level of aggregation, there is no difference between the two types of monetary aggregates in the two Central Banks. At the broader level, Divisia M2 has a slight edge over traditional M2 in predicting real GDP in BEAC. In BCEAO, simple sum M2 dominates Divisia M2 in explaining inflation.
\end{abstract}

JEL Classification: B22 C32 C43 C53 E52

Keywords: Divisia monetary aggregates; simple sum monetary aggregates; in-sample analysis; out-of-sample analysis 


\section{Introduction}

During the 1970's, monetary aggregate have been assigned an important role in the implementation of monetary policy. Monetary aggregates M1 and M2 were considered as good guides for monetary policy. Since the 1980s, the traditional relationship between money and policy target variables has deteriorated in many countries. Consequently, money growth targets have begun to lose their importance and in the last decade, have almost completely lost their central role in the conduct of monetary policy. Therefore, there is no consensus concerning the role of monetary aggregates in the implementation of monetary policy. Friedman (1997) demonstrates that monetary aggregates are no more useful. He argues that instability of money velocity due to financial innovations is the major explanation of the downgrading of quantitative controls. On the contrary, Adam and Hendry (2000) show that money conserves its role in the implementation of monetary policy, since it still fulfils the properties of stability, controllability and information content.

Beyond this debate, a third series of studies emerged from the literature. These studies compare the empirical performances of Divisia monetary aggregates and simple sum monetary aggregates. A review of the literature shows that there is no convergence in the findings. In fact, some studies confirm the empirical superiority of Divisia monetary aggregates on the traditional ones in the implementation of monetary policy (Schunk, 2001; Dahalan et al, 2005; Darrat et al, 2005). For Drake and Mills (2005), the superiority of Divisia monetary aggregates on empirical ground is not always established.

However, these studies are limited to developed countries, although Habibullah (1999) and Dahalan et al (2005) create Divisia monetary aggregates in some Asian countries. There is lack of studies concerning African countries. Therefore, two African Central Banks are taken as case study namely BEAC and BCEAO. The main reason which justifies the choice of these Central Banks is the fact that their monetary policies are theoretically based on monetarist hypotheses. According to this hypothesis, the primary objective of monetary policy is to guarantee price stability by controlling the evolution of monetary aggregates. Another reason is that, like the majority of the Central Banks in the world, the two Central Banks construct their official monetary aggregates by simply summing their monetary components.

Despite their widespread use, economists have long recognized that the simple summation approach to monetary aggregation is less than optimal. Referring to the simple sum index, Fisher (1922) wrote that "the simple arithmetic average produces one of the very worst of index numbers". The traditional monetary aggregates are criticized because monetary assets are entered in the aggregate with a weight equal to unity. The implication of this is that there is a perfect substitution between all component assets. According to microeconomic demand theory, if indeed these assets were perfect substitutes, rational economic agents would choose to hold only one asset class unless all assets have the same user cost. However, there is sufficient evidence on differences in user costs and on imperfect substitution between components of monetary aggregates. Divisia monetary aggregates were introduced by the seminal work of Barnett (1980) to overcome the theoretical deficiencies of traditional 
monetary aggregates. Barnett (1980) constructs monetary aggregates, which take into account the degree of monetarity of different monetary assets with a rigorous application of theories of aggregation and index numbers. Hence, Divisia index is theoretically the most relevant in the sense that it is constructed with solid theoretical foundations.

On the empirical ground, the following evidences can be drawn from monetary policy perspectives. Since the 1990's, BEAC and BCEAO were engaged in some important financial reforms. These reforms introduced the liberalization of interest rates and the removal of credit ceilings which are ingredients for financial innovations. Generally, financial innovations lead to substantial changes in the behavior of monetary aggregates, in terms of their capacity to predict price level and GDP. In addition, we observe that the volume of demand deposits (DDBEAC) and quasi money (QMBEAC) increases more than the quantity of fiduciary money (MFBEAC) in BEAC; and in BCEAO furthermore, there is no substantial change in the evolution of components of monetary aggregates over the period (see figures 1 and 2). Especially for BEAC, this evidence suggests an increasing proportion of monetary components which have a positive implicit or explicit rate of return. Then, take into account the evolution of Divisia monetary aggregates make sense.

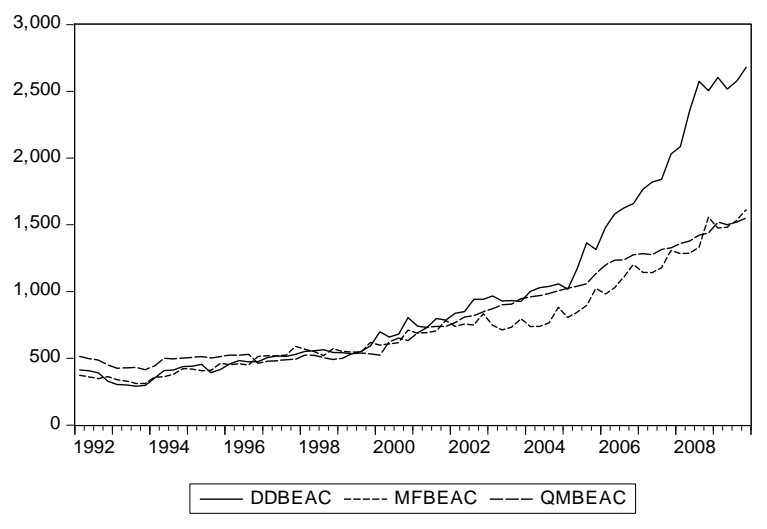

Figure 1: The evolution of fiduciary money (MFBEAC), demand deposits (DDBEAC) and quasi money (QMBEAC), BEAC

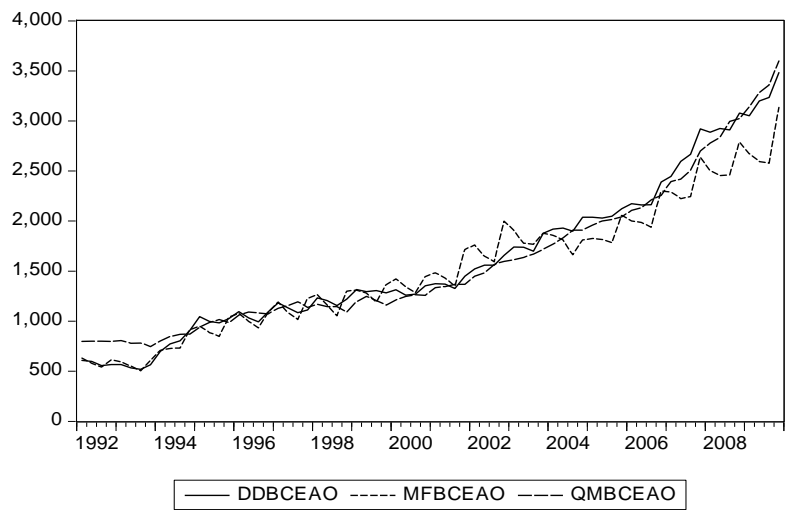

Figure 2: The evolution of fiduciary money (MFBCEAO), demand deposits (DDBCEAO) and quasi money (QMBCEAO), BCEAO 
The purpose of the paper is therefore to provide empirical evidence by comparing the performance of the simple sum and Divisia monetary aggregates. This evidence will come from a comparison of the relative performance of alternative aggregates in terms of growth captured by real GDP, and inflation captured by consumer price index within the period 1992.1- 2007.4(Note 3) Two approaches are used in the paper. The first approach uses variance decomposition in an in-sample forecasting perspective. In the second approach, the forecasting exercise will be one of true out-of sample forecasting.

The paper is organized as follow. Section 2 provides a brief review of literature of the empirical performances of Divisia monetary aggregates versus simple sum monetary aggregates. Section 3 describes the construction of Divisia monetary aggregates and other data of study. In section 4, we outline the research methodology. Section 5 summarizes the main results of the study and in section 6 we conclude.

\section{Divisia versus Simple Sum Monetary Aggregates: A Review of Empirical Literature}

Following the seminal work of Barnett (1980), many studies have examined the usefulness of Divisia monetary aggregates in the conduct of monetary policy especially in developed countries. Cockerline and Murray (1981) compare Divisia with simple sum aggregates for Canada and conclude that Divisia aggregates display greater parameter stability. Barnett et al (1984) show that Divisia money velocity $\mathrm{M}_{3}$ is more stable than the other monetary indicators in the USA within the period 1968-1978. In another study, these authors use many criteria (stability of demand function, controllability of money supply, causality between money and income) to compare Divisia monetary aggregates and traditional ones. With regard to the criteria aforementioned, Barnett et al (1984) find that none of monetary aggregates have better empirical performances. However, the study demonstrates that at the high level of aggregation, Divisia monetary aggregates are better than simple sum in the conduct of monetary policy. This result is confirmed by Spindt (1984). Ishida (1984) concludes that Divisia M2 should be considered along with the simple-sum aggregates in conducting monetary policy.

Serletis and King (1993) conclude that Divisia aggregates are potentially more useful than simple-sum aggregates for forecasting nominal income. In UK, Belongia and Chrystal (1991) demonstrate that Divisia monetary aggregates are more closely related to the growth of nominal GDP, and have stable money demand functions. Swofford and Whitney (1991) emphasis that Divisia monetary aggregates forecast better the evolution of inflation within the period 1970- 1985 in USA. The empirical superiority of Divisia monetary aggregates is also found by Schunk (2001), Dahalan et al (2005), Darrat et al (2005).

Some studies produce mixed results. Fluri and Spoerndli (2000) find that Divisia M1 predicts short-run price movements better than simple sum M1 but does not predict long-run price movements more accurately. Lecarpentier and Renou (2000) study the properties of Divisia monetary aggregate $\mathrm{M}_{3}$ compared to the simple-sum monetary aggregate $\mathrm{M}_{3}$ from 1982 to 1997. They conclude that the result of causality between money and income are very close 
for the two monetary aggregates. By, looking at the information content, the superiority of Divisia monetary aggregate is confirmed. Along the same line, Elger et al (2006) demonstrate that the aggregation method has no significative impact on inflation and growth forecasting.

The principal drawback coming from the existing literature is the quasi absence of studies concerning CFA franc Zone (FZC) countries. Otherwise, the majority of studies comparing the simple sum and Divisia monetary aggregates consider their relative in sample performance using alternative models except the studies of Barnett et al (1984), Swofford and Whitney (1991), and Schunk (2001) which focus on out-of-sample forecasting. The main innovation of the paper is that we evaluate the empirical performances of alternative monetary aggregates using both in- sample and out-of-sample forecasting.

\section{Divisia Monetary Aggregates and Other Data of the Study}

\subsection{Data}

The Divisia monetary aggregates are computed for each country. Therefore, the regional Divisia monetary aggregates are the sum of national Divisia monetary aggregates. The following variables are used to run empirical investigation especially to construct Divisia monetary aggregates: $\mathrm{M}_{1}, \mathrm{M}_{2}$, savings and time savings deposit rates, statutory reserves requirements, the interbank money market, total deposits for each Central Bank.

The other data used in the study are real GDP, inflation. The consumer price index is used to capture inflation. The consumer price index of each Central Bank is a GDP weighted average of national consumer price index. Real GDP of each zone is the sum of real GDP across the members' countries. Since the data on real GDP are on annual basis, we use the procedure of Goldstein and Khan (1976) to obtain quarterly data in each country and these data have been corrected for seasonality.

\subsection{The Construction of Divisia Monetary Aggregates}

To construct Divisia monetary aggregates, three steps are required: selection of monetary assets, computation of user cost money and the choice of the weighted and aggregation method.

\subsubsection{The selection of monetary assets}

The chosen monetary aggregates are M1 and M2 for BEAC and BCEAO. The composition of the monetary aggregates is as follow:

$\checkmark \quad$ M1: currency in circulation + demand deposits

$\checkmark \quad$ M2: M1+ saving and time deposits

\subsubsection{The computation of the user cost of money}

Following Barnett $(1978,1980)$, the user cost of money is the price of transaction service of each monetary asset. The user cost of each component is proportional to the interest income 
forgone by holding it rather than a pure store of wealth asset which is an asset that yields a high rate of return but provides no monetary services. In nominal terms, the user cost is defined as:

$$
\pi_{i t}^{*}=\frac{P_{t}\left(R_{t}-r_{i t}\right)}{\left(1+R_{t}\right)}
$$

where $R_{t}$ is the benchmark rate at time $t, r_{i t}$ is asset i's rate of return at time $t$ and $P_{t}$ is the consumer price index. In real term, equation (1) becomes:

$$
\pi_{i t}^{*}=\frac{\left(R_{t}-r_{i t}\right)}{\left(1+R_{t}\right)}
$$

Equation (2) is therefore describes as the real user cost. The user cost of a monetary asset depends on the return of that asset. Currency is seen as pure money and is given a zero rate of return. Demand deposits also bear no explicit interest rate. However, if explicit interest is not paid to depositors, a bank can make indirect payments to customers like making loans to depositors at preferential interest rate, providing free consultations and offering gifts. In this sense, demand deposit can bear an implicit interest rate. Then, to set the user cost of demand deposits, we follow Dahalan et al (2005). They use the implicit rate of return defined by Klein (1974) which claims that banks indirectly pay a competitive rate of return to their depositors. Klein's return on demand deposits is computed as:

$r_{D}=r_{A}\left(1-\left[\frac{R}{D}\right]\right)$ where $r_{D}$ is the implicit rate of return, $\left[\frac{R}{D}\right]$ is ratio of reserves to deposit, $r_{A}$ is the bank's base lending rate.

The benchmark rate of return is defined as the maximum expected yield of a pure store of-value asset. This benchmark asset is specifically assumed to provide no liquidity or other monetary service, and is held solely to transfer wealth inter temporally. As explained by Barnett et al (1992), it is included to establish a nonmonetary alternative. Empirically, the interest rate which has the higher return will be taken as the benchmark rate (Dahalan et al, 2005). This is justified by the fact that in theory, the benchmark rate offers the highest return (Serletis and Molik, 2000). Following Binner et al (2009), the inter-bank lending rate is taken as benchmark rate in our study.

\subsubsection{Aggregation and weighted method}

Following Barnett (1980) and Barnett et al (1984), the Tornquist-Theil discrete time approximation to the Divisia quantity index is used to compute each Divisia monetary aggregate (DM): 


$$
D M_{t}=D M_{t-1} \prod_{i=1}^{n}\left(\frac{M_{i t}}{M_{i t-1}}\right)^{S_{i t}^{*}}
$$

where $S_{i t}^{*}$ is the average of $S_{i t}$ and $S_{i t-1}$ with $S_{i t}$ defined as the expenditure share of monetary asset $\mathrm{i}$ at time $t$ and $M_{i t}$ represents the balance of asset $\mathrm{i}$ at time $t$. The expenditure share is:

$$
s_{i t}=\frac{\pi_{i t} M_{i t}}{\sum_{j=1}^{n} \pi_{j t} M_{j t}}
$$

Figure 3 and figure 4 give the evolution of expenditure shares in BEAC and BCEAO. S1, S2 and S3 are the weighted coefficient on currency, demand deposits and quasi money respectively. The expenditure shares are within 0 and 1 meaning that they have coherent economic values. However, the weighted coefficient on currency is the highest one. This confirms the fact that as an asset is closer to the pure money the expenditure share is close to one. The evolution of S3 confirms equally the theoretical predictions. In fact, the expenditure share is close to zero as we drive away from pure money. Figure 3 and 4 show that the weighted varies over time. In BEAC, we observe that after 2001Q1 the expenditure share on demand deposits becomes greater than the expenditure share on quasi money. The explanation behind this feature can be the increasing proportion of demand deposits in the total assets relatively to quasi money.

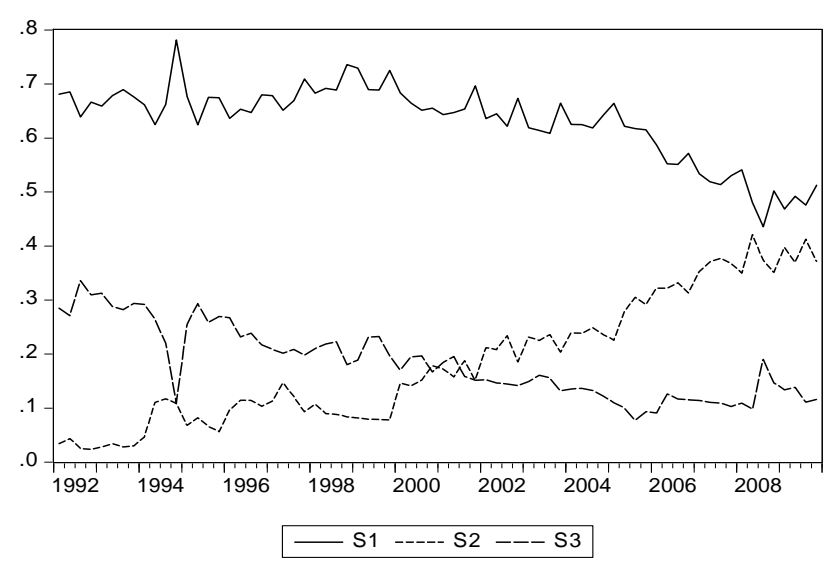

Figure 3: The evolution of expenditure shares in BEAC 


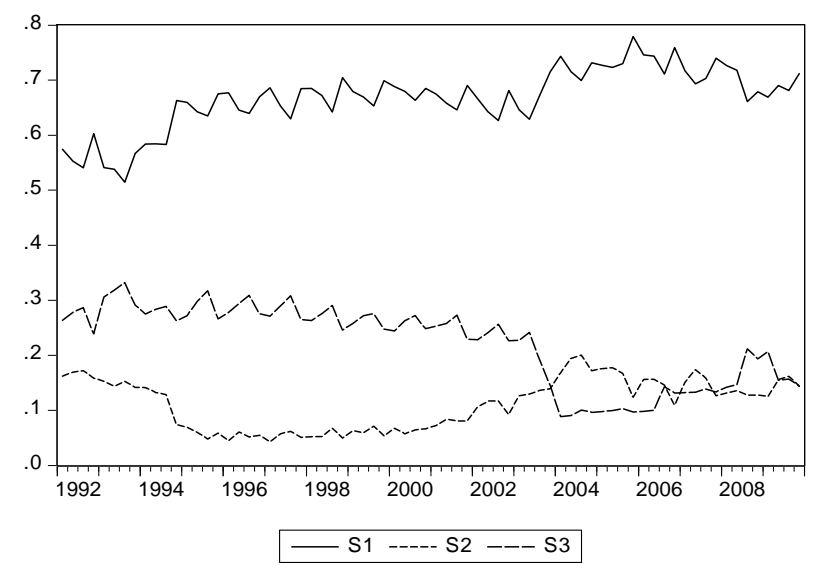

Figure 4: The evolution of expenditure shares in BCEAO

\subsection{Divisia versus Simple Sum Monetary Aggregates}

Table 1 summarizes the descriptive statistics of simple sum monetary aggregates and Divisia monetary aggregates.

Table 1: Summary statistic of monetary aggregates

\begin{tabular}{cccc}
\hline Central Bank & Variables & Mean & Standard deviation \\
\hline \multirow{4}{*}{ BEAC } & M1 & 7.167888 & 0.455495 \\
& M1D & 6.237531 & 0.511884 \\
& M2 & 7.588747 & 0.421116 \\
& M2D & 6.471139 & 0.410794 \\
BCEAO & M1 & 7.845084 & 0.434587 \\
& M1D & 6.984210 & 0.459682 \\
& M2 & 8.261289 & 0.401002 \\
\hline
\end{tabular}

The results show that the evolution of simple sum and Divisia monetary aggregates in BEAC and BCEAO is similar since the values are closed. This highlights the fact that there can be a little difference between the two types of monetary aggregates. The graphical evolution of the monetary aggregates confirms this point (see figures 5, 6, 7 and 8).

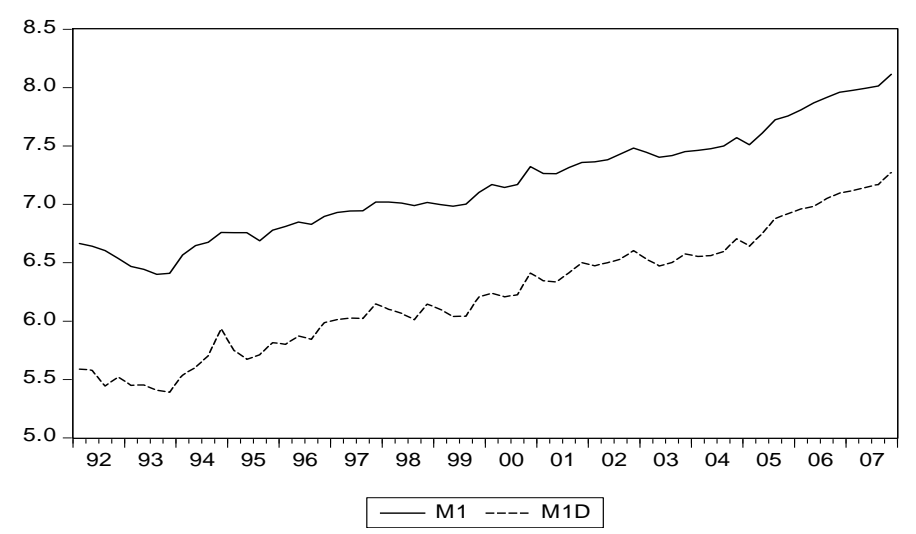

Figure 5: Simple Sum M1 and Divisia M1, BEAC 


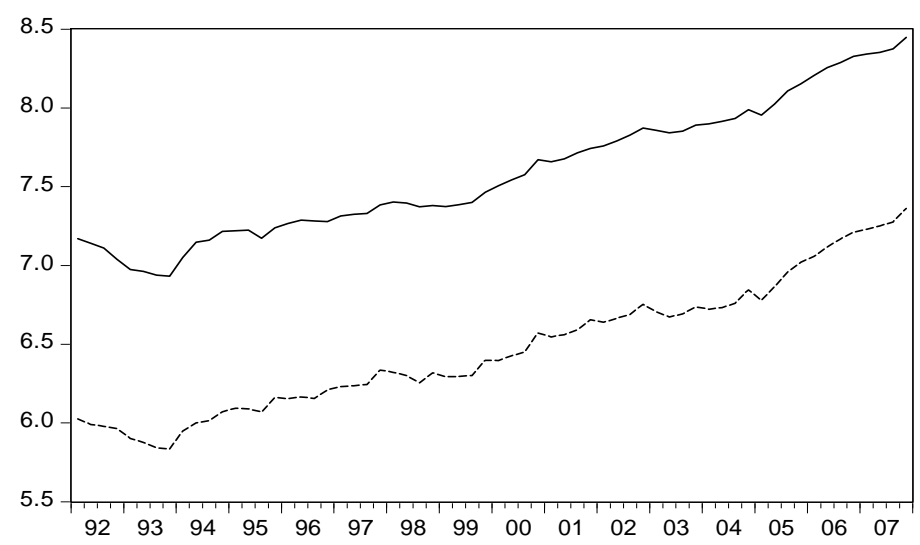

$$
-\mathrm{M} 2 \text {---- M2D }
$$

Figure 6: Simple Sum M2 and Divisia M2, BEAC

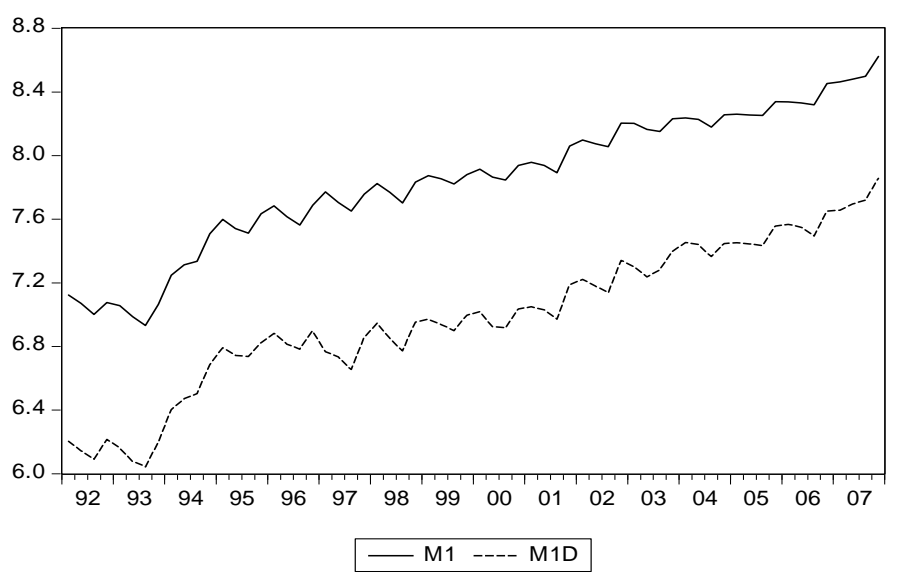

Figure 7: Simple Sum M1 and Divisia M1, BCEAO

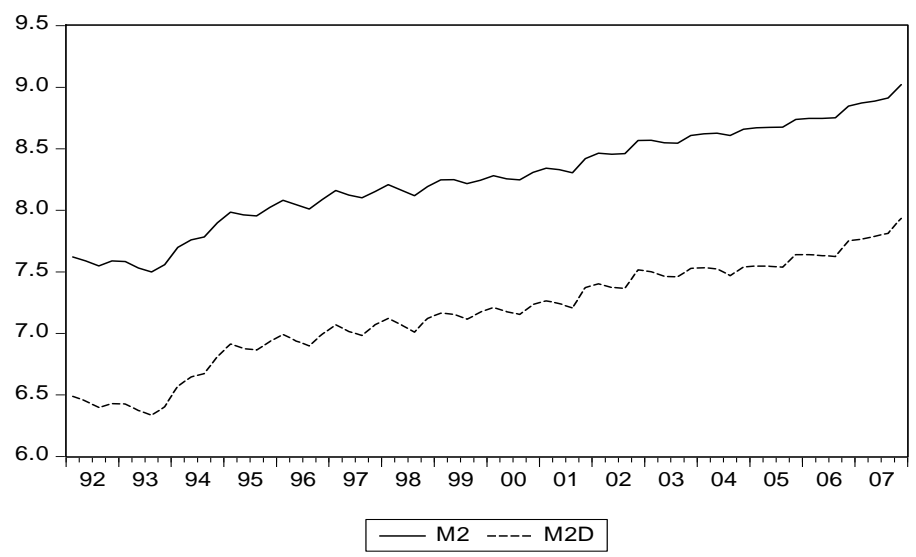

Figure 8: Simple Sum M2 and Divisia M2, BCEAO

Growth differences between the two types of monetary aggregates are plotted in figures 9, 10, 11 and 12. We observe that the Divisia monetary aggregates are more volatile than their simple sum counterparts in BEAC. The same remark can be made for BCEAO. The computation of standard deviation of the growth rate of each monetary aggregate gives some insight to this observation. For example, standard deviations for growth rate in BEAC are: 5.28 for tm1, 8.05 for tm1d, 3.82 for tm2 and 4.54 for tm2d. Overall, the evolution of the growth rates of monetary aggregates in BEAC 


\section{Macrothink}

shows some differences. In this sense, the correlation between growth rates tm 1 and tm1d is 0.7749 and between tm2 and tm2d is 0.8618. Ishida and Nakamura (2000) reported a diverse result. The reason is that despite the financial liberalization, the financial assets in $\mathrm{m} 2$ are still less. In BCEAO, the correlations are respectively 0.9054 and 0.9820 between tm 1 and tm1d, and tm2 and tm2d meaning there is no difference in the evolution of the growth rates. This is justified by the fact that within the period, the evolution of different monetary assets shows the same path.

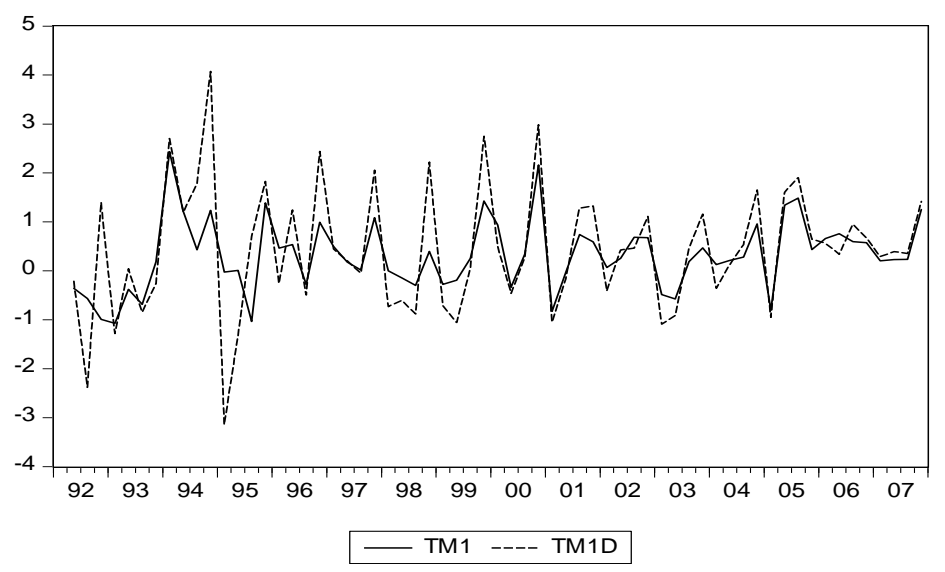

Figure 9: Growth rate of simple sum (tm1) and Divisia (tm1d), BEAC

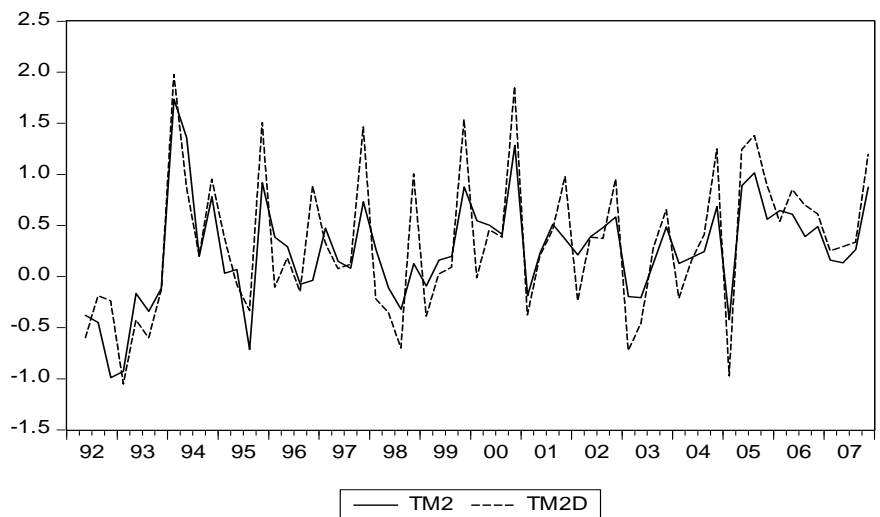

Figure 10: Growth rate of simple sum (tm2) and Divisia (tm2d), BEAC

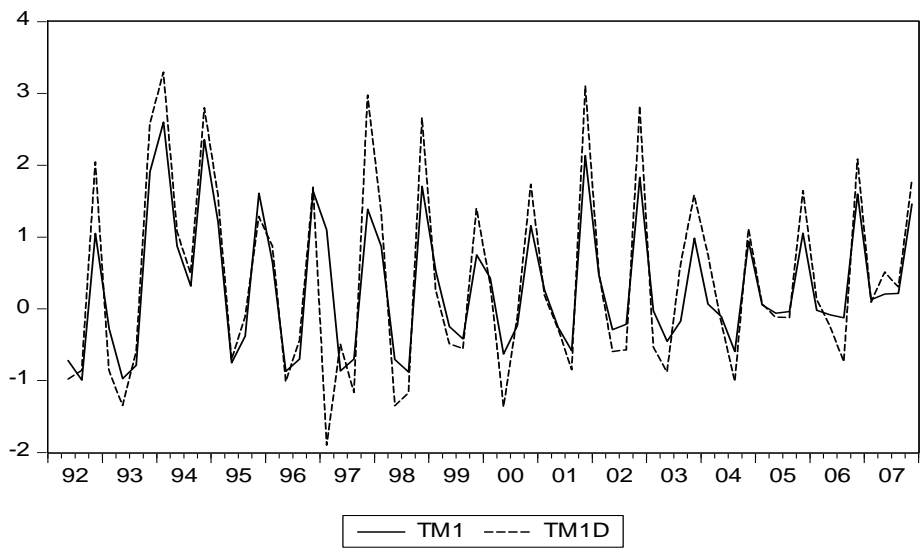

Figure 11: Growth rate of simple sum (m1) and Divisia (m1d), BCEAO 


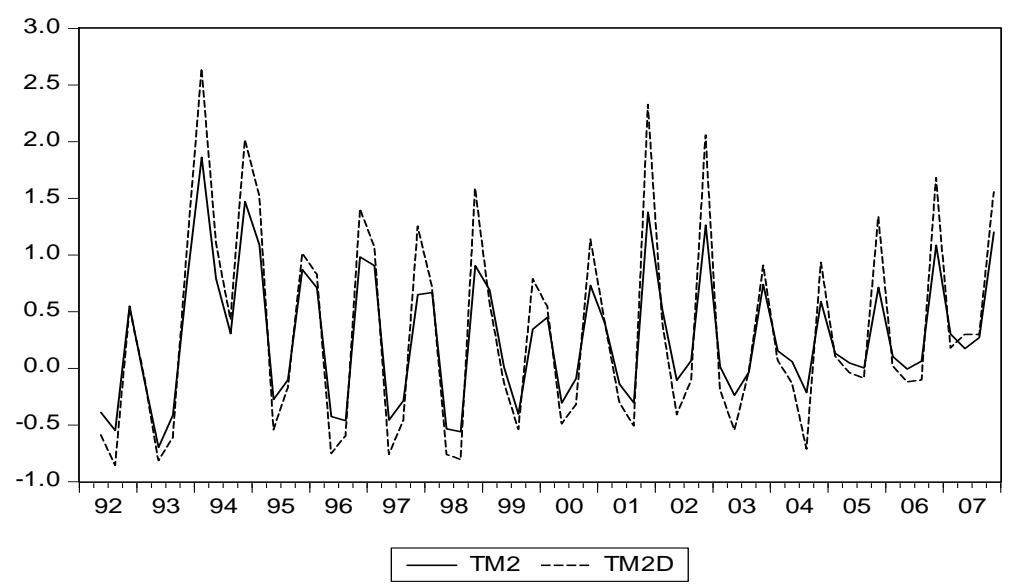

Figure 12: Growth rate of simple sum (m2) and Divisia (m2d), BCEAO

\section{Methodology}

\subsection{The Variance Decomposition Analysis}

The variance decomposition analysis is run from a VAR model. Let $X_{t}$ be a $k$-dimensional vector of dependent variables at time $t$. In the $\operatorname{VAR}(p)$ model, the dynamics $X_{t}$ are governed by the following process:

$$
X_{t}=\alpha_{0}+A_{1} X_{t-1}+\ldots \ldots \ldots+A_{p} X_{t-p}+\varepsilon_{t}
$$

where $\alpha_{0}$ is a vector of intercepts, $A_{l}, l=1, \ldots, p$ are $k \times k$ coefficient matrices and $\varepsilon_{t}$ is a white noise distributed disturbance vector. Estimates of the coefficient matrices are obtained using ordinary least squares.

\subsection{The Out-Of-Sample Analysis: Graphical Observation and Computation of RMSE}

We evaluate forecasts of both real GDP and inflation by using graphical observation of the actual and forecasted variables, and the computation of RMSE drawn from a VAR specification. Let $X_{t}$ be a $k$-dimensional vector of dependent variables at time $t$. A conditional $t+1$ forecast of $X$ is obtained from:

$$
E\left(X_{t+1}\right)=\alpha_{0}+A_{1} X_{t}+\ldots \ldots \ldots+A_{p} X_{t-p+1}
$$

for each $t$, where the notation $E_{t}($.$) indicates that the expectation is calculated$ conditional on the information set $X_{t}=\left\{x_{t}, x_{t-1}, \ldots \ldots\right\}$. The conditional $t+1$ forecast in Eq. (7) is a special case of the conditional dynamic $t+\tau$ forecast, $E_{t}\left(X_{t+\tau}\right)$, where forecasted values of $\mathbf{x}$ should be used for certain lags (depending on the forecast horizon and the number of included lags).

To obtain forecast values of our main variables (real GDP and inflation), a VAR model will be estimated through 2003:4 and forecast will be generated for the period 2004:1- 2007:4. Having forecasted values, we proceed to graphical observation; three curves are figured per 
graphic; the first one is the actual variable of either real GDP or inflation and the two other are the forecast values coming from VAR estimation with alternative monetary aggregates.

The root-mean-square error (RMSE) is a frequently used measure of the differences between values predicted by a model or an estimator and the values actually observed. These individual differences are also called residuals, and the RMSE serves to aggregate them into a single measure of predictive power. RMSE is the most frequently used evaluation measure in the forecasting literature. This criterion is defined as follows:

$$
R M S E=\left[\frac{1}{K} \sum_{t=2005 Q 4+\tau}^{2007 Q 4}\left(E_{t-\tau}\left[Z_{t}\right]-Z_{t}\right)^{2}\right]^{\frac{1}{2}}
$$

where $Z$ is used to denote either real GDP or inflation, $K$ is the total number of out-of-sample forecasts, and $\tau$ is the forecast horizon. In our study, $K=16$.

\section{The Main Results}

\subsection{Unit Root Results}

In BEAC, the following variables have no unit root in level: M1D, M2D, CPI, TDBEAC; the same result is achieved by M1, M2, M1D, M2D, CPI and TDBCEAO in the BCEAO. As concern the other variables, test statistics shows that the hypothesis of a unit root cannot be rejected at the one or five percent level after one differencing. According to ADF results, we specify a VAR model in level; in the VAR specification, the differentiated form is taken for the variables which are not stationary in level.

\subsection{Evolution of Inflation and Real GDP in FZC Countries: A Weak Contribution of Monetary Aggregates}

The evaluation is made by the variance decomposition analysis drawing from VAR models. In our specification, we considered Sims's (1992) classic 4-variables VAR, consisting in the interest rate, the logged money supply, the logged price level, and logged real GDP in that order. Table 2 and table 3 report the result of variance decomposition analysis respectively in BEAC and BCEAO. The results in table 2 show that the contribution of monetary aggregate to price level variation is less than $15 \%$. At all horizons, inflation rate is better explained by Divisia M2. However, variance decompositions show that innovations in money explain small percentages of the variance of real GDP; but traditional M2 perform better. 
Table 2: Variance decomposition results, BEAC

\begin{tabular}{lllllllll}
\hline Horizon & \multicolumn{1}{l}{ Price Level } & \multicolumn{7}{c}{ Real GDP } \\
\hline & M1 & M1D & M2 & M2D & M1 & M1D & M2 & M2D \\
4 & 10.3017 & 12.6373 & 8.3768 & 13.5339 & 14.9778 & 11.7257 & 16.7692 & 11.8419 \\
6 & 13.6883 & 14.1389 & 13.8017 & 14.5561 & 12.3833 & 11.5384 & 13.6203 & 11.4513 \\
8 & 14.3484 & 14.2021 & 14.4780 & 14.6007 & 11.4779 & 11.9837 & 12.8557 & 10.5718 \\
10 & 14.3629 & 14.3724 & 14.6090 & 14.7612 & 10.3424 & 12.9290 & 11.6844 & 11.5715 \\
\hline
\end{tabular}

Table 3 point out that the contribution of money to inflation and GDP variability is worst in the BCEAO. One exception is the percentage of simple sum monetary aggregate which explain price level variability. In fact, M2 explains $15.65 \%, 19.40 \%, 22.18 \%$ and $24.55 \%$ respectively at 4, 6, 8 and 10 quarters.

Table 3: Variance decomposition results, BCEAO

\begin{tabular}{lllllllll}
\hline Horizon & \multicolumn{1}{l}{ Price Level } & \multicolumn{7}{c}{ Real GDP } \\
\hline & M1 & M1D & M2 & M2D & M1 & M1D & M2 & M2D \\
4 & 8.2436 & 0.4422 & 15.6546 & 3.3649 & 2.0627 & 1.6602 & 2.1967 & 1.5199 \\
6 & 7.2827 & 0.4190 & 19.4067 & 3.5028 & 2.0833 & 1.7086 & 2.1937 & 1.5174 \\
8 & 6.2503 & 0.7283 & 22.1840 & 3.4111 & 2.1032 & 1.7649 & 2.1945 & 1.5242 \\
10 & 5.3790 & 1.2286 & 24.5590 & 3.2751 & 2.1136 & 1.8021 & 2.1955 & 1.5276 \\
\hline
\end{tabular}

5.3 Forecasting Ability of Divisia Monetary Aggregates versus Simple Sum Monetary Aggregates

Figures 13 to 20 present the actual and the forecasted values of price level and real GDP from the alternatives aggregates in each Central Bank. For example, figure 13 compares the forecast of price level from the M1 VAR while figure 14 compares the forecast of real GDP from the M1 VAR in BEAC.

Considering figure 14 specifically, it appears that the two M1 aggregates are similar in their ability to predict real GDP. Also, there is no difference between traditional M1 and Divisia M1 in their capacity to forecast price in BEAC (figure 13).

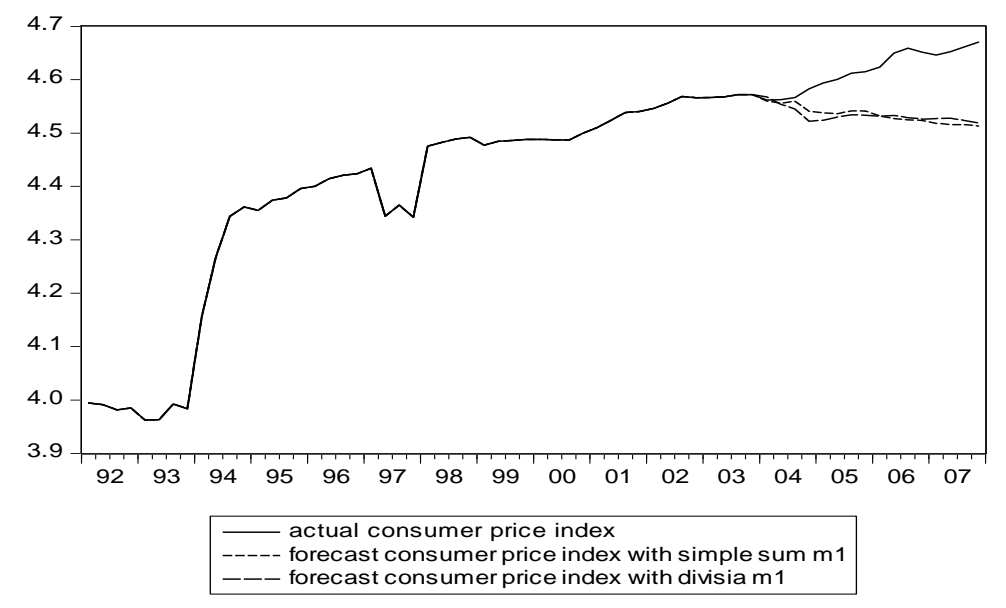

Figure 13: Price Level Forecasts, M1 BEAC 


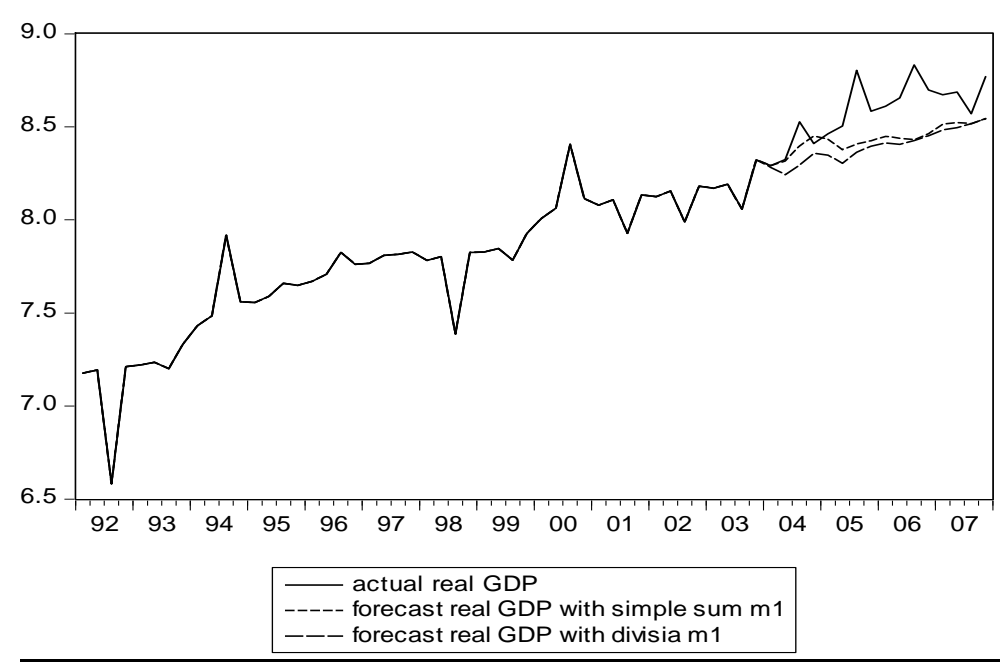

Figure 14: Real GDP Forecasts, M1 BEAC

The forecasting power of monetary aggregates relative to price level and real GDP in BCEAO exhibits a different path. In that sense, traditional M1 performs a little better in forecasting inflation whereas Divisia M1 leads to better empirical performance in its ability to forecast real GDP. In sum, these results confirm the fact that at the narrowest level of aggregation, the difference between simple sum monetary aggregation and Divisia monetary should be very small. This evidence was provided by Barnett et al (1984) and Schunk (2001).

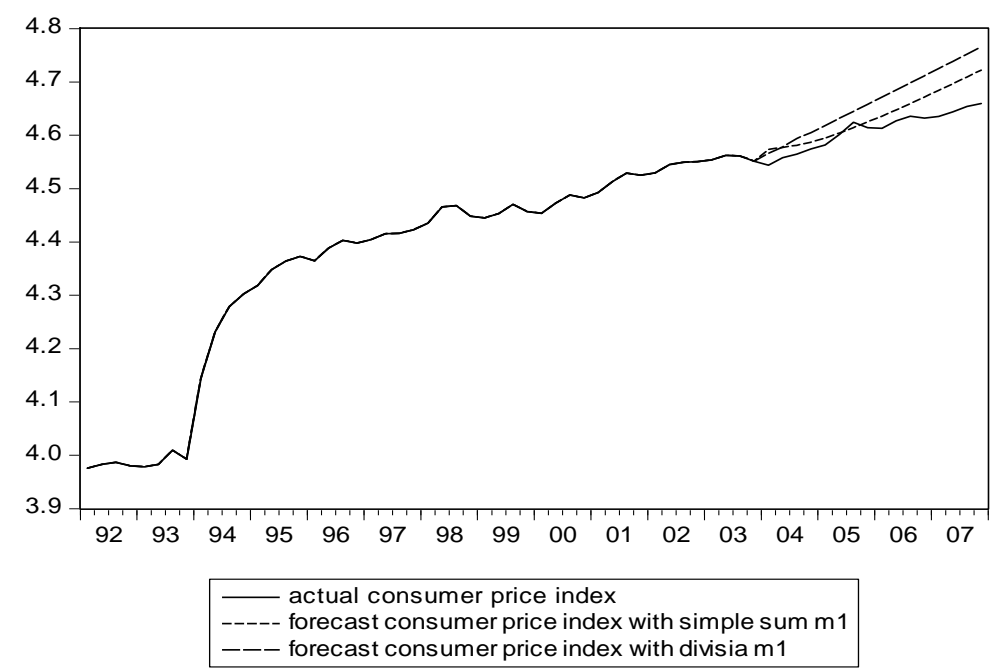

Figure 15: Price Level Forecasts, M1, BCEAO 


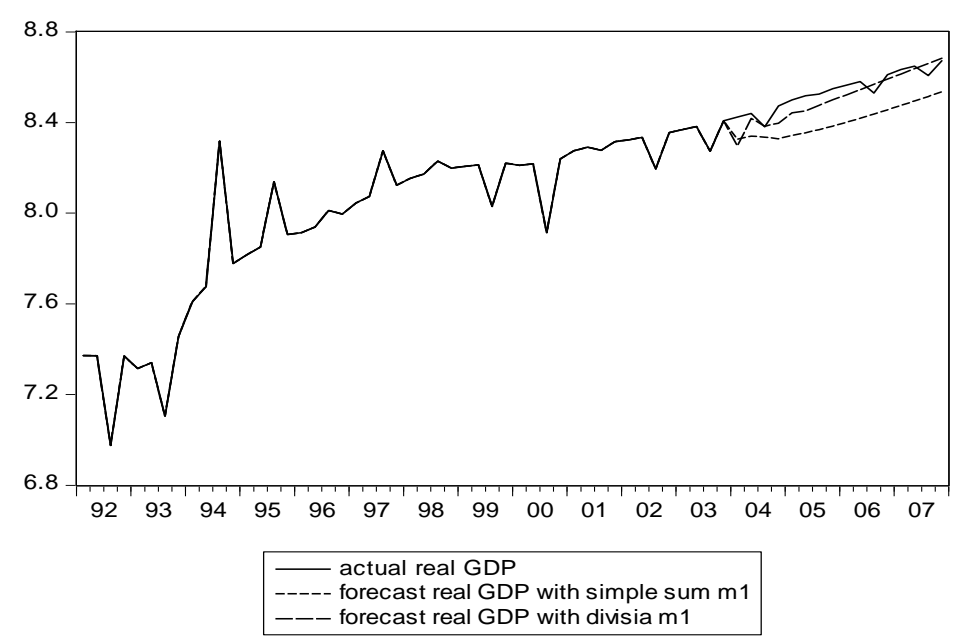

Figure 16: Real GDP Forecasts, M1 BCEAO

At level of aggregation broader than M1, the forecast evaluation leads to divergent conclusions relatively to each Central Bank. In the BEAC, no divergence emerges between the simple sum and Divisia monetary aggregate in their ability to forecast the price level. A careful observation of figure 18 shows that Divisia M2 has a slight edge over traditional M2 in predicting real GDP.

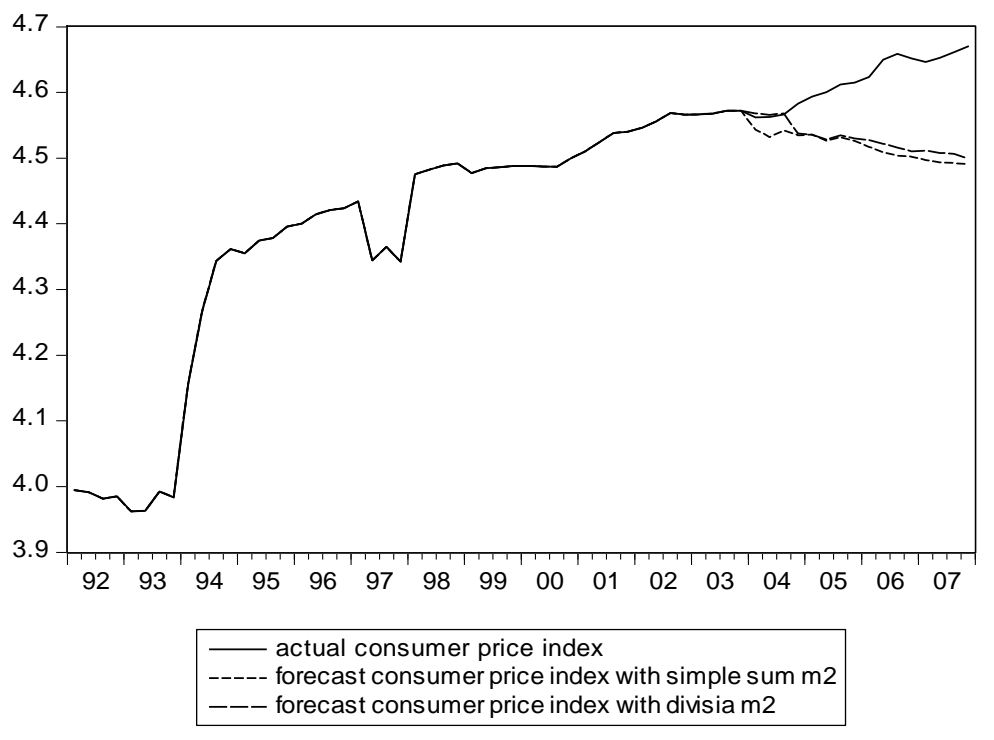

Figure 17: Price Level Forecasts, M2 BEAC 


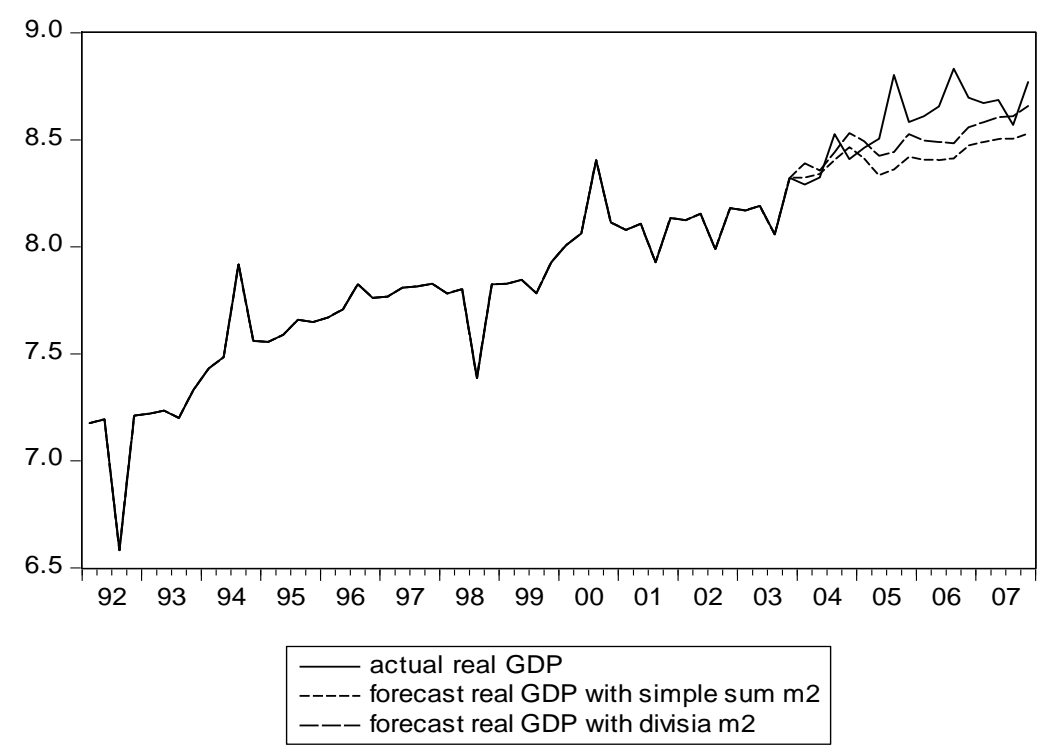

Figure 18: Real GDP Forecasts, M2 BEAC

Looking at the results from BCEAO, we can assert that the method of aggregation does not influence the forecasting ability of monetary aggregates. While the predictability power of Simple sum $\mathrm{M}_{2}$ and Divisia $\mathrm{M}_{2}$ with regard to real GDP is quite the same, Divisia M2 dominates traditional M2 as predictor of prices.

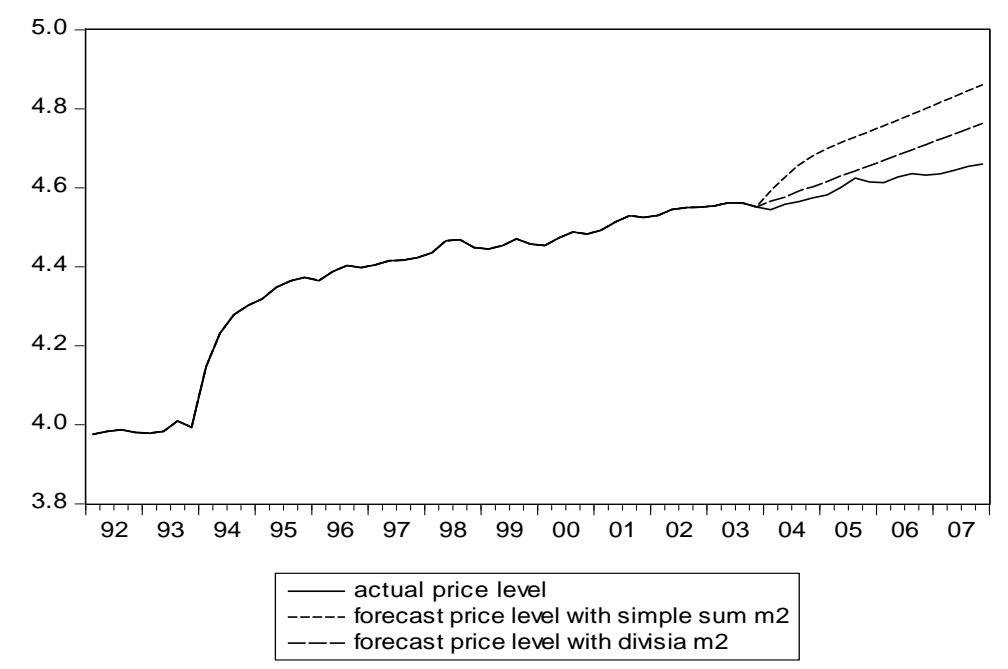

Figure 19: Price Level Forecasts, M2, BCEAO 


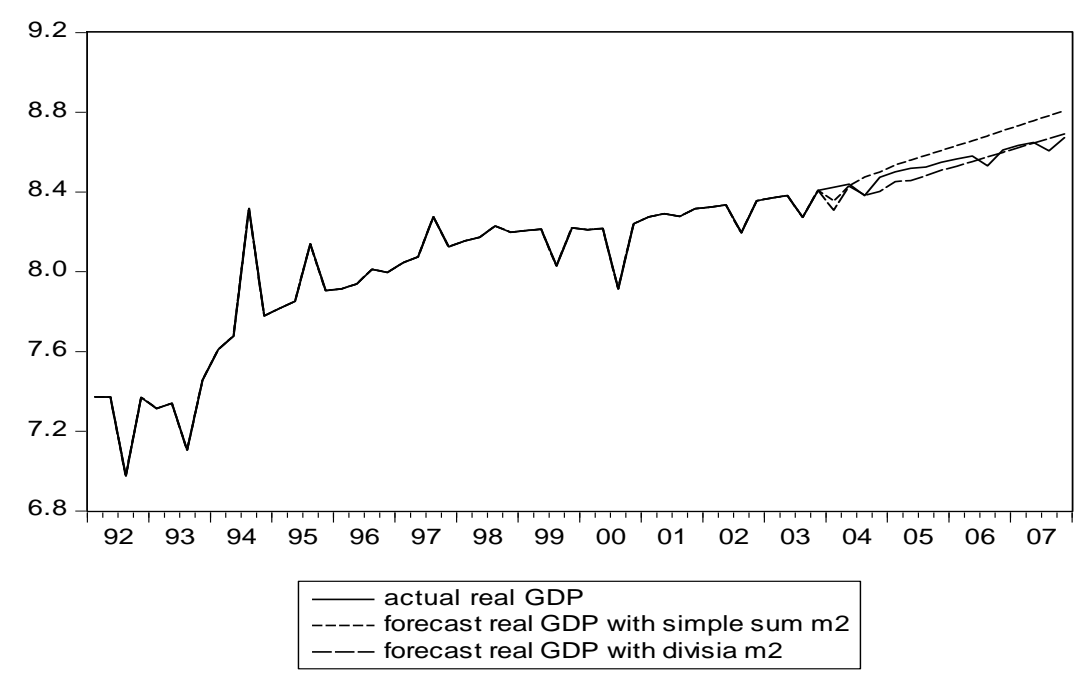

Figure 20: Real GDP Forecasts, M2 BCEAO

In an effort to give some insights to our findings, we compute forecast RMSE from the VAR models (see table 6). The statistics in table 6 support the simple sum and Divisia comparisons offered above. We can also compare the ability of each monetary aggregate, irrespective of the type of monetary aggregate, to forecast price level and real GDP. Table 6 shows that the construction of Divisia monetary aggregates does not lead to substantial changes in targeting inflation and real GDP. The same conclusion is found by Elger et al (2006).

Table 5: Forecast RMSE, alternative monetary aggregates

\begin{tabular}{cccc}
\hline Central Bank & Variables & Price Level & Real GDP \\
\hline \multirow{4}{*}{ BEAC } & M1 & 0.0556 & 0.0937 \\
& M1D & 0.0554 & 0.0932 \\
& M2 & 0.0554 & 0.0935 \\
& M2D & 0.0556 & 0.0954 \\
BCEAO & M1 & 0.0549 & 0.1247 \\
& M1D & 0.0550 & 0.1249 \\
& M2 & 0.0547 & 0.1248 \\
\hline
\end{tabular}

\section{Conclusion}

The objective of this paper was to provide empirical evidence comparing the performance of simple sum and Divisia monetary aggregates. In fact, Divisia monetary aggregates were introduced by the seminal work of Barnett (1980) to overcome the theoretical deficiencies of simple sum monetary aggregates. Numerous studies have provided empirical comparisons of the Divisia aggregates to traditional aggregates. The majority of these studies were focused on developed economies and there is a quasi-absence of studies concerning African countries. Also, the majority of studies comparing the simple sum and Divisia monetary aggregates consider either their relative in sample performance or their out-of-sample method. This paper was mainly focused on the two approaches 
within the period 1992.1 and 2007.4. The first approach uses variance decomposition in an in-sample forecasting perspective. In the second approach, the forecasting exercise has been one of true out-of sample forecasting.

We find that the choice of monetary aggregation procedure is not crucial when evaluating the relationship between money and economic activity. In other words, none of the monetary aggregates dominate in their ability to target inflation and GDP.

\section{References}

Adam, C., \& Hendry, S. (2000). Le modèle vectoriel à correction d'erreurs basé sur $\mathrm{M}_{1}$ : quelques extensions et applications, in La Monnaie, La Politique Monétaire et Les Mécanismes de Transmission, Actes du Colloque Tenu à La Banque du Canada en Novembre 1999, Ottawa, Banque du Canada, p. 175-208.

Bahmani-Oskooee M. (1991). The demand for money in open economy: the United Kingdom. Applied Economics, 23(6), 1037-1042. http://dx.doi.org/10.1080/00036849100000006

Bahmani-Oskooee, M., \& Shin, S. (2002). Stability of the Demand for Money in Korea. $\begin{array}{llll}\text { International Economic Journal, } & \text { 85-95. }\end{array}$ http://dx.doi.org/10.1080/10168730200080015

Barnett, W. A., Fisher, D., \& Serletis, A. (1992). Consumer theory and the demand for money. Journal of Economy Literature, 30(4), 2086-2119.

Barnett, W. A., Offenbacher, E. K., \& Spindt, P. A. (1984). The new Divisia monetary aggregates. Journal of Political Economy, 92(6), 1049-1085. http://dx.doi.org/10.1086/261275

Barnett, W. A. (1978). The user coast of money. Economic Letters, 1(2), 145-149. http://dx.doi.org/10.1016/0165-1765(78)90051-4

Barnett, W. A. (1980). Economic monetary aggregate: an application of index number and aggregation theory. Journal of Econometrics, 14(1), 11-48. http://dx.doi.org/10.1016/0304-4076(80)90070-6

Belongia, M.T., \& Chrystal, K.A. (1991). An admissible monetary aggregate for the united kingdom. The Review of Economics and Statistics, 73(3), 497-503. http://dx.doi.org/10.2307/2109574

Binner, J. M., Bissoondeeal, R. K., Elger, C. T., Jones, B. E., \& Mullineux, A. W. (2009). Admissible monetary aggregates for Euro area. Journal of International Money and Finance, 28(1), 99-114. http://dx.doi.org/10.1016/j.jimonfin.2008.07.007

Cockerline, J. P., \& Murray, J. D. (1981). A comparison of alternative methods of monetary aggregation: some preliminary evidence. Bank of Canada, Technical Report, 28.

Dahalan, J., Sharma, S. C., \& Sylwester, K. (2005). Divisia monetary aggregates and money demand for Malaysia. Journal of Asian Economics, 15(6), 1137-1153. 
http://dx.doi.org/10.1016/j.asieco.2004.11.016

Darrat, A. F., Chopin, M. C., \& Lobo, B. J. (2005). Money and macroeconomic performance: revisiting divisia money. Review of Financial Economics, 14(2), 93-101. http://dx.doi.org/10.1016/j.rfe.2004.05.002

Drake, L., \& Mills, T. (2005). A new empirically weighted monetary aggregate for the United States. Economic Inquiry, 43(1), 138-157. http://dx.doi.org/10.1093/ei/cbi010

Duca, V. D. (2000). Financial technology shocks and the case of the missing $\mathrm{M}_{2 .}$ Journal of Money, Credit and Banking, 32(4), 820-839. http://dx.doi.org/10.2307/2601185

Elger, T., Jones, B. E., \& Nilsson, B. (2006). Forecasting with monetary aggregates: recent evidence for the United States. Journal of Economics and Business, 58(5), 428-446. http://dx.doi.org/10.1016/j.jeconbus.2006.06.004

Fisher, I. (1922), The Making of Index Numbers. Houghton Mifflin, Boston.

Fluri, R., \& Spoerndli, E. (2000). Simple-sum versus money in Switzerland: Some empirical results, in Belongia M. T. \& Binner J. M. (Eds.), Divisia monetary aggregate: Theory and practice. New York: Palgrave.

Friedman, B.M. (1997). The Rise and the fall of money growth targets as guidelines of U.S monetary policy. Journal of Monetary Economics, 4(3), 279-304.

Friedman, B.M., \& Kuttner, K.N. (1992). Money, income, prices and interest rates. American Economic Review, 82(3), 472-490.

Gaab, W. (1996). On the demand for Divisia and simple-sum $\mathrm{M}_{3}$ in Germany, 1960-1993. in Financial Innovation, Banking and Monetary Aggregates, Mullineux A.\& Elgar E. (Eds.) Publishing.

Goldstein, M., \& Khan, M. S. (1976). Large versus small price changes and the demand for imports. IMF Staff Papers, 23, 200-225. http://dx.doi.org/10.2307/3866671

Ishida, K. (1984). Divisia monetary aggregates and demand for money: a japanese case. Bank of Japan Monetary and Economic Studies, 2(1), 49-80.

Ishida, K., \& Nakamura, K. (2000). Broad and narrow divisia monetary aggregates for Japan, in Belongia M. T. \& Binner J. M. (Eds.), Divisia monetary aggregate: Theory and practice. New York: Palgrave.

Johansen, S., \& Juselius, K. (1990). Maximum likelihood estimation and influence on cointegration with application to the demand of money. Oxford Bulletin of Economics and Statistics, 52(2),

http://dx.doi.org/10.1111/j.1468-0084.1990.mp52002003.x

Johansen, S. (1988). Statistical analysis of cointegration vectors. Journal of Economic $\begin{array}{llll}\text { Dynamics } \quad \text { and } & \text { Control, }\end{array}$ http://dx.doi.org/10.1016/0165-1889(88)90041-3 
Klein, B. (1974). Competitive interest payments on bank deposits and the long run demand for money. American Economy Review, 64(6), 931-949.

Lecarpentier Moyal, S., \& Renou Maissant, P. (2000). Les agrégats de monnaie ont-ils toujours un rôle à jouer dans la conduite de la politique monétaire ? L'apport des indices de Divisia. Economie Appliquée, (1), 91-116.

Schunk, D. L. (2001). The relative forecasting performance of the Divisia and simple sum Monetary Aggregates. Journal of Money, Credit and Banking, 33(2), 272-283. http://dx.doi.org/10.2307/2673885

Sekine, T. (1998). Financial liberalization, the wealth effect and the demand for broad money in Japan. Monetary Economic Studies, Bank of Japan. 35-46. http://dx.doi.org/10.1016/0164-0704(93)90054-P

Serletis, A. King M. (1993). The role of money in Canada. Journal of Macroeconomics, 15(1), 91-107.

Serletis A., \& Molik E. (2000). Les agrégats monétaires et politique monétaire, in La Monnaie, La Politique Monétaire et Les Mécanismes de Transmission, Actes du Colloque tenu à La Banque du Canada en Novembre 1999, Ottawa, Banque du Canada, p. 121-156.

Spindt P. A. (1984). Modelling the monetary multiplier and the controllability of the Divisia monetary aggregates. Review of Economics and Statistics, 66(2), 314-319. http://dx.doi.org/10.2307/1925834

Swofford, J. L., \& Whitney, J. L. (1991). The composition and the construction of monetary $\begin{array}{llll}\text { aggregates. } & \text { Economic } & \text { Inquiry, } & \text { 29(4), }\end{array}$ http://dx.doi.org/10.1111/j.1465-7295.1991.tb00859.x

\section{Notes}

Note 1. The BEAC is a common Central Bank for six countries namely Cameroon, Central Africa Republic, Congo, Gabon, Chad and Equatorial Guinea.

Note 2. The BCEAO is in charge of the monetary policy of eight countries namely Ivory Coast, Senegal, Togo, Burkina Faso, Mali, Benin, Bissau-Guinea and Niger.

Note 3. The sample period would be the same for each Central Bank. The beginning of the sample is chosen according to the adoption of monetary targeting policy by the BEAC. In fact, the BEAC was the last to focus on monetary aggregates as intermediate targets of monetary policy.

\section{Copyright Disclaimer}

Copyright reserved by the author(s).

This article is an open-access article distributed under the terms and conditions of the Creative Commons Attribution license (http://creativecommons.org/licenses/by/3.0/). 